\title{
Assessment of Pathogenic Contamination and Antimicrobial Activity of Selected Herbal Medicinal Remedies in Mbarara City, South Western Uganda
}

\section{Guti Walker ( $\sim$ gutereswalker90@gmail.com )}

Department of Microbiology, Faculty of Medicine, Mbarara University of Science and Technology https://orcid.org/0000-0001-6091-0207

\section{Benson Musinguzi}

Department of Microbiology and Immunology, School of Medicine, King Ceasor University https://orcid.org/0000-0002-1211-4617

\section{Kirya Musa}

Department of surgery, Makerere University, P.O. Box 7072 Kampala, Uganda

Charity Mutesi

Department of Public health, Makerere University, P.O. Box 7072 Kampala, Uganda

\section{Henry Zamarano}

Department of Microbiology, Faculty of Medicine, Mbarara University of Science and Technology

\section{Godfrey Manirakiza}

Department of Internal Medicine, Faculty of Medicine, Mbarara University of Science and Technology, Mbarara, Uganda

\section{Ivan Muhwezi}

Department of Microbiology, Faculty of Medicine, Mbarara University of Science and Technology, Mbarara, Uganda

\section{Kennedy Kassaza}

Department of Microbiology, Faculty of Medicine, Mbarara University of Science and Technology, Mbarara, Uganda https://orcid.org/0000-0003-2097-4622

\section{Francis Tusingwire}

Department of Microbiology, Faculty of Medicine, Mbarara University of Science and Technology, Mbarara, Uganda

\section{Charles Opendi}

Department of Medical Laboratory Science, Mbarara University of Science and Technology, P.O Box 1410, Mbarara, Uganda

\section{Herbert Itabangi}

Department of Microbiology and Immunology, Faculty of Health Sciences, Busitema University, P.O BOX, 1460, Mbale, Uganda https://orcid.org/0000-0003-3010-2537 


\section{Research Article}

Keywords: Herbal medicines, Contamination, Antimicrobial Activity

Posted Date: June 2nd, 2021

DOI: https://doi.org/10.21203/rs.3.rs-582967/v1

License: (c) (i) This work is licensed under a Creative Commons Attribution 4.0 International License.

Read Full License 


\section{Abstract}

Background: Herbal formulations in Mbarara have been used in the treatment and management of several disease conditions extensively overtime due to low cost compared to empirical synthetic medicine, however evidenced that they can be contaminated with dangerous pathogenic organisms which are all tailored to handling practices, storage, and other environmental conditions thus, the need to further asses these herbs for safety to the consumers.

Materials and methods: Forty-five (45) liquid herbal formulations for the treatment and management of communicable infections were purchased on the open market. All Samples were cultured on plate count agar for colony counts and then subcultured on different laboratory media and then analyzed for antimicrobial activity using the agar diffusion method.

Results: Out of the 45 herbal formulations, 32(71.1\%) were contaminated while 13 (28.9\%) were not. Out of the organisms isolated from individual formulations, 19 (59.4\%) had Bacillus subtillis and S. aureus, 4(12.5\%) had C. freundi and Proteus mirabilis, 2(6.3\%), C.divergens, 1(3.1\%) Rhodotorula, 5(15.6\%) Aspergillus spp, had E. cloace. 1 (3.1\%) had Klebsiella spp. Of these, 29(87.9\%) had contaminants within acceptable limits of less than $10^{3} \mathrm{CFU} / \mathrm{mL}$, while $12\left(36.4 \%\right.$ ) beyond $10^{3} \mathrm{CFU} / \mathrm{m}$. Out of the 45 formulations, not even one could qualify for pharmaceutical use, all MICs all were $>1000 \mathrm{mcg} / \mathrm{mL} 64.4 \%$ ) were active while $16(35.6 \%)$ had no activity.

Conclusion: Herbal formulations in Mbarara are contaminated with various microbes and have very limited antimicrobial activity, herbalists therefore should be trained on good harvesting, safe handling, storage, and good manufacturing practices of these medicinal raw materials and their products, responsible authorities should enact policies and regulations to guide the herbalists and protect the public from adverse effects of consuming these unverified herbal medicinal remedies.

\section{Background}

Herbal medicines' use is the exploration of utilising homes' grown solutions for treating various forms of health disorders including but not limited to gastrointestinal, eye defects and respiratory [1]. Nearly $80 \%$ of the people in the world depend on these local medicines for primary health care needs [2-4]. In developing countries, almost hundreds of people utilise these mostly plant-exploited herbal products for microbial infections [5-7]. However, these can either be a source of great medical value or complications such as drug resistance [1, 8-10].

In East Africa and Uganda, the use of herbal medicines is a common habit with about $80 \%$ of the population accustomed to such a tradition, especially in rural settings $[2,11]$. To some extent, this practice has been backed by a demonstration of antimicrobial bioactivity against microbiological agents by some of the commercially available herbal remedies [12-14]. 
In this regard, the Ugandan government, for instance, is encouraging the use of such formulations and an integration of their applications into the orthodox medicine framework $[15,16]$. However, there are no systems in Uganda to monitor and control the herbal medicine chain of production, their hygiene conditions during production, and bioactivity spectrum, thus these products could get contaminated with pathogens leading to secondary infections [17]. Contaminants such as Staphylococcus, Escherichia coli, Shigella, and bread moulds have already been reported in some of these products. Thus, consumers of these products are at risk of exposure to such pathogens $[3,18]$. This is further complicated by their unchecked administration and prescription guidelines, for instance, under or over dosing with herbal products could lead to clinical complications such as development of drug resistance and death. Therefore, this study aimed at determining the contamination levels and antimicrobial activity of randomly selected locally branded antimicrobial herbal medicinal remedies on the open market in Mbarara city, South Western Uganda.

\section{Ethical approval}

The proposal was submitted to the Department of Microbiology, Faculty of Medicine Review Committee (FRC) and approved by the Institutional Review Committee (IRC) of Mbarara University of Science and Technology.

\section{Results}

\section{Common microbiological contaminants of herbal formulations around Mbarara municipality.}

Forty five (45) herbal formulations (samples) were selected for this study, 20 (52.6\%) of the samples had Bacillus subtillis, 6 (15.8\%) Citrobacter freundii, 5(13.2 \%) Enterobacter cloacae, 2(5.3\%) with Citrobacter divergens, and 1(2.6\%) Aspergillus species, 1(2.6\%) Rhodotorula, 1(2.6\%) Staphylococcus aureus, 1(2.6

$\%)$ Klebsiella spp and $1(2.6 \%)$ Proteus mirabilis all being represented in equal measure as shown in Tables 1 and 2.

Table 1: List of bacterial and fungal microbial contaminants as per recruited coded herbal sample formulations. 


\begin{tabular}{|c|c|c|c|c|c|}
\hline Sample & $\begin{array}{l}\text { Total bacterial count } \\
\text { (CFU/mL). }\end{array}$ & $\begin{array}{l}\text { Fungal count } \\
(\mathrm{CFU} / \mathrm{mL}) .\end{array}$ & Isolate. & REFFE & E RANGES \\
\hline & & & & $\begin{array}{l}\text { Accep } \\
\text { Conta }\end{array}$ & $\begin{array}{l}\text { imit } \\
\text { ed }\end{array}$ \\
\hline W01 & 0 & 0 & - & $<10^{3}$ & $>10^{3}$ \\
\hline W02 & 0 & 0 & - & $<10^{3}$ & $>10^{3}$ \\
\hline W03 & 0 & 0 & - & $<10^{3}$ & $>10^{3}$ \\
\hline W04 & 0 & 0 & - & $<10^{3}$ & $>10^{3}$ \\
\hline W05 & 33 & 0 & B.subtillis & $<10^{3}$ & $>10^{3}$ \\
\hline W06 & $1 \times 10^{4}$ & 0 & B.subtillis & $<10^{3}$ & $>10^{3}$ \\
\hline W07 & $1 \times 10^{5}$ & 0 & C.freundi & $<10^{3}$ & $>10^{3}$ \\
\hline W08 & 158 & 0 & E.cloace & $<10^{3}$ & $>10^{3}$ \\
\hline W09 & 0 & 156 & $\begin{array}{l}\text { Aspergillus } \\
\text { spp,Rhodotorula }\end{array}$ & $<10^{3}$ & $>10^{3}$ \\
\hline$W 10$ & $1 \times 10^{4}$ & 0 & C.freundi & $<10^{3}$ & $>10^{3}$ \\
\hline W11 & 3 & 0 & B.subtillis & $<10^{3}$ & $>10^{3}$ \\
\hline W12 & 18 & 0 & B.subtillis & $<10^{3}$ & $>10^{3}$ \\
\hline W13 & 197 & 0 & B.subtillis & $<10^{3}$ & $>10^{3}$ \\
\hline W14 & 0 & 0 & - & $<10^{3}$ & $>10^{3}$ \\
\hline W15 & 60 & 0 & - & $<10^{3}$ & $>10^{3}$ \\
\hline W16 & $1 \times 10^{5}$ & 0 & E.cloace & $<10^{3}$ & $>10^{3}$ \\
\hline W17 & 60 & 0 & B.subtillis, S.aureus & $<10^{3}$ & $>10^{3}$ \\
\hline W18 & 67 & 0 & B.subtillis & $<10^{3}$ & $>10^{3}$ \\
\hline W19 & 0 & 0 & - & $<10^{3}$ & $>10^{3}$ \\
\hline W20 & $1 \times 10^{6}$ & 0 & C.divergens & $<10^{3}$ & $>10^{3}$ \\
\hline$W 21$ & $1 \times 10^{5}$ & 0 & E.cloace & $<10^{3}$ & $>10^{3}$ \\
\hline
\end{tabular}




\begin{tabular}{|c|c|c|c|c|c|}
\hline$W 22$ & 22 & 0 & B.subtillis & $<10^{3}$ & $>10^{3}$ \\
\hline W23 & $1 \times 10^{5}$ & 0 & B.subtillis & $<10^{3}$ & $>10^{3}$ \\
\hline$W 24$ & 31 & 0 & B.subtiliis & $<10^{3}$ & $>10^{3}$ \\
\hline$W 25$ & 0 & 0 & - & $<10^{3}$ & $>10^{3}$ \\
\hline$W 26$ & $1 \times 10^{4}$ & 0 & P.mirabilis., C.freundi & $<10^{3}$ & $>10^{3}$ \\
\hline$W 27$ & 0 & 0 & - & $<10^{3}$ & $>10^{3}$ \\
\hline W28 & 0 & 0 & - & $<10^{3}$ & $>10^{3}$ \\
\hline$W 29$ & 36 & 0 & B.subtillis & $<10^{3}$ & $>10^{3}$ \\
\hline W30 & 156 & 0 & B.subtillis & $<10^{3}$ & $>10^{3}$ \\
\hline W31 & 170 & 0 & B.subtillis & $<10^{3}$ & $>10^{3}$ \\
\hline W32 & $1 \times 10^{4}$ & 0 & C.freundi & $<10^{3}$ & $>10^{3}$ \\
\hline W33 & 95 & 0 & B.subtillis & $<10^{3}$ & $>10^{3}$ \\
\hline W34 & 64 & 0 & B.subtillis & $<10^{3}$ & $>10^{3}$ \\
\hline W35 & $1 \times 10^{5}$ & 0 & B.subtillis & $<10^{3}$ & $>10^{3}$ \\
\hline W36 & 206 & 0 & B.subtillis & $<10^{3}$ & $>10^{3}$ \\
\hline W37 & $1 \times 10^{4}$ & 0 & B.subtillis & $<10^{3}$ & $>10^{3}$ \\
\hline W38 & 162 & 0 & E.cloace & $<10^{3}$ & $>10^{3}$ \\
\hline W39 & 0 & 0 & - & $<10^{3}$ & $>10^{3}$ \\
\hline W38 & 0 & 0 & - & $<10^{3}$ & $>10^{3}$ \\
\hline$W 40$ & 0 & 0 & - & $<10^{3}$ & $>10^{3}$ \\
\hline W41 & 0 & 0 & - & $<10^{3}$ & $>10^{3}$ \\
\hline W42 & 147 & 0 & E.cloace & $<10^{3}$ & $>10^{3}$ \\
\hline W43 & 205 & 0 & Klebsiella spp & $<10^{3}$ & $>10^{3}$ \\
\hline W44 & $1 \times 10^{5}$ & 0 & C.divergens & $<10^{3}$ & $>10^{3}$ \\
\hline W45 & 107 & & B.subtillis. & $<10^{3}$ & $>10^{3}$ \\
\hline
\end{tabular}


Table 2: Summary of common microbial contaminants in the samples herbal formulations

\begin{tabular}{|c|c|c|}
\hline Contaminants & Number of herbal formulations with contaminants & Percentage (\%) \\
\hline Bacillus subtillis & 20 & 52.6 \\
\hline Citrobacter freundi & 6 & 15.8 \\
\hline Enterobacter cloaceae & 5 & 13.2 \\
\hline Aspergillus species & 1 & 2.6 \\
\hline Rhodotorula & 1 & 2.6 \\
\hline Staphylococcus aureus & 1 & 2.6 \\
\hline Citrobacter divergens & 2 & 5.3 \\
\hline Klebsiella spp & 1 & 2.6 \\
\hline Proteus mirabilis & 1 & 2.6 \\
\hline Total & 38 & \\
\hline
\end{tabular}

Levels of contamination in herbal formulations on the open market around Mbarara city.

In this study, we graded in accordance with the individual contaminants as shown in Table 3 below. However, only formulations with B. subtillis 4(8.8\%), C. freundi 4(8.8\%), C. divergens 2 (4.4\%), E. cloacae 1 $(2.2 \%)$, and P. mirabilis $1(2.2 \%)$ showed highly an unacceptable level of contamination. While contamination with the organism within acceptable limits were B. subtillis $16(35.6 \%)$, C. freundi $2(4.4 \%)$, Enterobacter cloace 4(4.5\%), Rhodotorula and Aspergillus spp 1(2.2\%), Staphylococcus aureus 1(2.2\%), Klebsiella spp 1(2.2\%), Proteous mirabilis 1(2.2\%) as shown in Table 3.

Table 3: levels of contamination in herbal formulations 


\begin{tabular}{|c|c|c|c|c|}
\hline \multirow[t]{3}{*}{ No } & \multirow[t]{3}{*}{ Contaminant } & \multicolumn{3}{|c|}{$\begin{array}{l}\text { Number of herbal formulations and their Level of } \\
\text { contamination }(n=45)\end{array}$} \\
\hline & & $\begin{array}{l}\text { No } \\
\text { contamination }\end{array}$ & $\begin{array}{l}\text { Acceptable limit(1- } \\
\text { 1000)cfu/ml }\end{array}$ & $\begin{array}{l}\text { Highly } \\
\text { contaminated }\end{array}$ \\
\hline & & $0(\mathrm{cfu} / \mathrm{ml})$ & & $\begin{array}{l}\text { Greater than } \\
1000 \mathrm{cfu} / \mathrm{ml}\end{array}$ \\
\hline 1 & Bacillus subtillis. & $25(55.6 \%)$ & $16(35.6 \%)$ & $4(8.8 \%)$ \\
\hline 2 & Citrobacter fruendi & 39(86.7\%) & $2(4.4 \%)$ & $4(8.9 \%)$ \\
\hline 3 & Enterobacter cloace & $40(93.3 \%)$ & $4(4.5 \%)$ & $1(2.2 \%)$ \\
\hline 4 & $\begin{array}{l}\text { Rodotorula and } \\
\text { Aspergillus spp }\end{array}$ & $44(97.8 \%)$ & $2(2.2 \%)$ & $0(0.0 \%)$ \\
\hline 5 & Staphylococcus aureus & $44(97.8 \%)$ & $1(2.2 \%)$ & $0(0.0 \%)$ \\
\hline 6 & Citrobacter divergens & $43(95.6 \%)$ & $0(0.0 \%)$ & $2(4.4 \%)$ \\
\hline 7 & Klebsiella spp & $44(97.8 \%)$ & $1(2.2 \%)$ & $0(0.0 \%)$ \\
\hline 8 & Proteous mirabilis & $44(97.8 \%)$ & $0(0.0 \%)$ & $1(2.2 \%)$ \\
\hline
\end{tabular}

\section{Antimicrobial activity profiles against target organisms.}

Our study found that Out of the 45 herbal formulations, 29 (64.4\%) were active while 16(35.6\%) had no activity against all standard organisms, of the 29 active herbal formulations, 26(89.6\%) of the herbal formulations were active against staphylococcus aureus, 11(37.9\%) against Candida albicans. 9(31.03\%) against E.coli .The least activity was noted against Pseudomonas aeruginosa where $6(20.7 \%)$ of the herbal formulations acted against these microorganisms as shown in Tables 4 and $\mathbf{5}$ below.

Table 4: In vitro antibacterial activity of the herbal formulations $(n=45)$ 


\begin{tabular}{|c|c|c|c|c|}
\hline \multirow[t]{2}{*}{ Sample } & \multicolumn{4}{|c|}{ Zone of inhibition in $\mathrm{mm}$ ( antimicrobial activity) } \\
\hline & $\begin{array}{l}\text { S.aereus ATTC } \\
25923\end{array}$ & $\begin{array}{l}\text { E. coli ATTC } \\
25922\end{array}$ & $\begin{array}{l}\text { P.aeruginosa ATTC } \\
27583\end{array}$ & $\begin{array}{l}\text { C. albicans ATTC } \\
10231\end{array}$ \\
\hline W01 & 13 & 0 & 5 & 0 \\
\hline W02 & 12 & 3 & 3 & 0 \\
\hline W03 & 13 & 0 & 0 & 0 \\
\hline W04 & 9 & 0 & 0 & 4 \\
\hline W05 & 0 & 0 & 0 & 0 \\
\hline W06 & 7 & 0 & 3 & 0 \\
\hline W07 & 0 & 0 & 3 & 0 \\
\hline W08 & 0 & 0 & 0 & 0 \\
\hline W09 & 0 & 0 & 0 & 0 \\
\hline$W 10$ & 8 & 0 & 0 & 0 \\
\hline$W 11$ & 0 & 0 & 0 & 4 \\
\hline W12 & 0 & 0 & 0 & 0 \\
\hline W13 & 0 & 0 & 0 & 0 \\
\hline W14 & 8 & 0 & 0 & 0 \\
\hline$W 15$ & 12 & 0 & 0 & 0 \\
\hline$W 16$ & 6 & 0 & 0 & 6 \\
\hline W17 & 0 & 0 & 0 & 0 \\
\hline$W 18$ & 0 & 0 & 0 & 0 \\
\hline W19 & 7 & 0 & 0 & 0 \\
\hline$W 20$ & 4 & 0 & 0 & 8 \\
\hline W21 & 0 & 0 & 0 & 0 \\
\hline W22 & 7 & 7 & 0 & 0 \\
\hline$W 23$ & 17 & 0 & 0 & 0 \\
\hline W24 & 17 & 0 & 0 & 0 \\
\hline W25 & 0 & 3 & 0 & 3 \\
\hline
\end{tabular}




\begin{tabular}{|c|c|c|c|c|}
\hline W26 & 0 & 0 & 0 & 0 \\
\hline W27 & 20 & 18 & 0 & 19 \\
\hline W28 & 22 & 16 & 5 & 0 \\
\hline W29 & 33 & 0 & 0 & 0 \\
\hline W30 & 0 & 0 & 0 & 0 \\
\hline W31 & 0 & 0 & 0 & 0 \\
\hline W32 & 4 & 0 & 0 & 8 \\
\hline W33 & 6 & 0 & 0 & 0 \\
\hline W34 & 0 & 0 & 0 & 0 \\
\hline W35 & 0 & 0 & 0 & 0 \\
\hline W36 & 4 & 3 & 0 & 8 \\
\hline W37 & 0 & 0 & 0 & 0 \\
\hline W38 & 4 & 0 & 0 & 0 \\
\hline W39 & 0 & 0 & 0 & 0 \\
\hline W38 & 4 & 0 & 0 & 0 \\
\hline W40 & 17 & 20 & 24 & 32 \\
\hline W41 & 4 & 7 & 0 & 6 \\
\hline W42 & 0 & 0 & 0 & 0 \\
\hline W43 & 0 & 0 & 0 & 0 \\
\hline W44 & 6 & 3 & 0 & 8 \\
\hline W45 & 3 & 0 & 0 & 0 \\
\hline $\begin{array}{l}\text { Ciprofloxacin } \\
0.002 \mathrm{gm} / \mathrm{ml}\end{array}$ & 22 & 37 & 32 & \\
\hline $\begin{array}{l}\text { Fluconazole } \\
2 \mathrm{mg} / \mathrm{ml}\end{array}$ & & & & 42 \\
\hline
\end{tabular}

NOTE: zone of inhibition means the herbal formulation was active.

Table 5: Antimicrobial activity profiles (MICs) of different herbal formulations 


\begin{tabular}{|llll|}
\hline $\begin{array}{l}\text { Susceptible microorganism to the } \\
\text { herbal formulation }\end{array}$ & $\begin{array}{l}\text { Number of herbal of } \\
\text { formulations }(\mathbf{n = 4 5})\end{array}$ & $\begin{array}{l}\text { Percentage } \\
\text { (\%) }\end{array}$ & MIC $\leq 100 M C G$ \\
\hline Staphylococcus aureus & 26 & $89.7 \%$ & 0 \\
\hline Eschericia.coli & 8 & $27.6 \%$ & 0 \\
\hline Pseudomonas aeruginosa & 6 & $20.7 \%$ & 0 \\
\hline Candida albicans & 11 & $37.9 \%$ & 0 \\
\hline
\end{tabular}

Table 6: Concentrations of different herbal extracts and their respective minimum inhibitory concentrations. $(n=45)$ 


\begin{tabular}{|c|c|c|c|c|c|c|}
\hline \multirow{4}{*}{$\begin{array}{l}\text { Herbal } \\
\text { formulation }\end{array}$} & \multirow[t]{4}{*}{ INDICATION } & \multirow[t]{4}{*}{ Conc $(\mathrm{mcg} / \mathrm{ml})$} & \multicolumn{4}{|c|}{ ACTIVITY(MIC in mcg/ml) } \\
\hline & & & \multicolumn{4}{|c|}{ STANDARD ORGANISM ATCC STRAIN } \\
\hline & & & & & $P_{\text {Aeruainosa }}$ & c. \\
\hline & & & 25923 & 25922 & 27583 & 10231 \\
\hline W01 & $\begin{array}{l}\text { Candida, } \\
\text { syphilis and } \\
\text { UTIs }\end{array}$ & $9.2 \times 10^{5}$ & $2.3 \times 10^{5}$ & - & $2.3 \times 10^{5}$ & - \\
\hline W02 & $\begin{array}{l}\text { Candida and } \\
\text { UTI }\end{array}$ & $13.1 \times 10^{5}$ & 327500 & & $65.5 \times 10^{4}$ & - \\
\hline W03 & $\begin{array}{l}\text { Candida, UTI } \\
\text { and itching }\end{array}$ & $9.6 \times 10^{5}$ & $4.8 \times 10^{5}$ & & - & - \\
\hline W04 & $\begin{array}{l}\text { sore throat, } \\
\text { asthma and } \\
\text { bronchitis }\end{array}$ & $11.2 \times 10^{5}$ & - & - & - & $5.6 \times 10^{5}$ \\
\hline W05 & Diarrhea & $8.6 \times 10^{5}$ & - & - & - & - \\
\hline W06 & Cough & $10.3 \times 10^{5}$ & $51.5 \times 10^{4}$ & & - & - \\
\hline W07 & Syphilis & $7.7 \times 10^{5}$ & - & & - & - \\
\hline W08 & $\begin{array}{l}\text { Cough and } \\
\text { diarrhea }\end{array}$ & $13.3 \times 10^{5}$ & - & - & - & - \\
\hline W09 & Cough & $9.0 \times 10^{5}$ & - & - & - & - \\
\hline W10 & $\begin{array}{l}\text { Ulcers, } \\
\text { stomach } \\
\text { gas and } \\
\text { worms }\end{array}$ & $11.8 \times 10^{5}$ & $29.5 \times 10^{4}$ & & - & - \\
\hline W11 & $\begin{array}{l}\text { Mental } \\
\text { disorder, } \\
\text { typhoid, UTI }\end{array}$ & $10.8 \times 10^{5}$ & - & - & - & - \\
\hline W12 & $\begin{array}{l}\text { worms and } \\
\text { UTI }\end{array}$ & $12.1 \times 10^{5}$ & - & - & - & - \\
\hline W13 & $\begin{array}{l}\text { liver } \\
\text { intoxication, } \\
\text { food } \\
\text { poisoning }\end{array}$ & $2.9 \times 10^{4}$ & $7.3 \times 10^{3}$ & - & - & - \\
\hline W14 & $\begin{array}{l}\text { cough, sore } \\
\text { throat, } \\
\text { bronchitis }\end{array}$ & $11.8 \times 10^{5}$ & $29.5 \times 10^{4}$ & - & - & - \\
\hline W15 & $\begin{array}{l}\text { bacterial } \\
\text { infection }\end{array}$ & $2.9 \times 10^{4}$ & $1.813 \times 10^{3}$ & - & - & - \\
\hline
\end{tabular}




\begin{tabular}{|c|c|c|c|c|c|c|}
\hline W16 & $\begin{array}{l}\text { malaria and } \\
\text { bacterial } \\
\text { infection }\end{array}$ & $2.9 \times 10^{4}$ & $7.250 \times 10^{3}$ & - & - & - \\
\hline W17 & $\begin{array}{l}\text { worms and } \\
\text { diarrhea }\end{array}$ & $2.9 \times 10^{4}$ & - & - & - & - \\
\hline W18 & $\begin{array}{l}\text { diarrhea, } \\
\text { dental } \\
\text { carries, }\end{array}$ & $9.9 \times 10^{5}$ & - & & & \\
\hline W19 & $\begin{array}{l}\text { allergy, } \\
\text { infections, } \\
\text { insomnia, }\end{array}$ & $11.5 \times 10^{5}$ & $5.75 \times 10^{5}$ & - & - & - \\
\hline W20 & Wounds & $2.9 \times 10^{4}$ & - & - & - & - \\
\hline W21 & $\begin{array}{l}\text { stomach } \\
\text { pain and } \\
\text { diarrhea }\end{array}$ & $2.9 \times 10^{4}$ & - & - & - & - \\
\hline W22 & $\begin{array}{l}\text { stomach } \\
\text { pain and } \\
\text { diarrhea }\end{array}$ & $8.0 \times 10^{5}$ & $4.0 \times 10^{5}$ & - & - & - \\
\hline W23 & $\begin{array}{l}\text { gonorrhea, } \\
\text { UTI and } \\
\text { candida }\end{array}$ & $2.9 \times 10^{4}$ & $1,8 \times 10^{3}$ & - & - & - \\
\hline W24 & $\begin{array}{l}\text { Cough and } \\
\text { sore throat }\end{array}$ & $2.9 \times 10^{4}$ & $1.8 \times 10^{3}$ & - & - & - \\
\hline W25 & $\begin{array}{l}\text { stomach } \\
\text { ache }\end{array}$ & $1.21 \times 10^{6}$ & - & - & - & - \\
\hline W26 & Diarrhea & $1.07 \times 10^{6}$ & $6.69 \times 10^{4}$ & & - & - \\
\hline W27 & Candida & $1.02 \times 10^{6}$ & $6.38 \times 10^{4}$ & & - & $6.375 \times 10^{3}$ \\
\hline W28 & $\begin{array}{l}\text { UTI, } \\
\text { syphilis, } \\
\text { chest pain }\end{array}$ & $11.2 \times 10^{6}$ & $1.4 \times 10^{5}$ & - & - & - \\
\hline W29 & Cough & $2.9 \times 10^{4}$ & $1.813 \times 10^{3}$ & & & \\
\hline W30 & $\begin{array}{l}\text { Candida, } \\
\text { cough, } \\
\text { diarrhea and } \\
\text { UTI }\end{array}$ & $2.9 \times 10^{4}$ & - & - & - & - \\
\hline W31 & Cough & $2.9 \times 10^{4}$ & - & - & - & - \\
\hline W32 & $\begin{array}{l}\text { Candida, } \\
\text { gonorrhea, } \\
\text { syphilis }\end{array}$ & $2.9 \times 10^{4}$ & - & - & - & $3.625 \times 10^{3}$ \\
\hline W33 & $\begin{array}{l}\text { Candida, } \\
\text { gonorrhea, }\end{array}$ & $2.9 \times 10^{4}$ & - & - & - & - \\
\hline
\end{tabular}


syphilis

\begin{tabular}{|c|c|c|c|c|c|c|}
\hline W34 & $\begin{array}{l}\text { Diarrhea, } \\
\text { appetite, } \\
\text { itching anus, } \\
\text { worms, } \\
\text { Stomach } \\
\text { ache }\end{array}$ & $2.9 \times 10^{4}$ & $1.813 \times 10^{3}$ & - & - & - \\
\hline W35 & $\begin{array}{l}\text { Boils and } \\
\text { wounds }\end{array}$ & $2.9 \times 10^{4}$ & $1.8 \times 10^{3}$ & - & - & - \\
\hline W36 & $\begin{array}{l}\text { Wounds and } \\
\text { sore throat }\end{array}$ & $2.9 \times 10^{4}$ & - & - & - & - \\
\hline W37 & $\begin{array}{l}\text { Stomach } \\
\text { gas }\end{array}$ & $2.9 \times 10^{4}$ & - & $1.813 \times 10^{3}$ & - & - \\
\hline W38 & $\begin{array}{l}\text { Cough, } \\
\text { stomach } \\
\text { ache, } \\
\text { diarrhea }\end{array}$ & $2.9 \times 10^{4}$ & - & - & - & - \\
\hline W39 & $\begin{array}{l}\text { clean } \\
\text { fallopian } \\
\text { tube, man } \\
\text { power }\end{array}$ & $1.22 \times 10^{6}$ & - & - & - & - \\
\hline W40 & $\begin{array}{l}\text { Mouth wash } \\
\text { and } \\
\text { antibacterial }\end{array}$ & $1.02 \times 10^{6}$ & $12.75 \times 10^{4}$ & $12.75 \times 10^{4}$ & $1.275 \times 10^{5}$ & $1.275 \times 10^{5}$ \\
\hline W41 & $\begin{array}{l}\text { Tonsillitis, } \\
\text { allergy, flu, } \\
\text { cough }\end{array}$ & $8.1 \times 10^{5}$ & - & - & - & - \\
\hline W42 & $\begin{array}{l}\text { Pressure } \\
\text {,cough } \\
\text { asthma }\end{array}$ & $1.21 \times 10^{6}$ & - & - & - & - \\
\hline W43 & Diarrhea & $2.9 \times 10^{4}$ & - & - & - & - \\
\hline W44 & $\begin{array}{l}\text { Cough, UTI } \\
\text { and } \\
\text { stomach } \\
\text { pain }\end{array}$ & $2.9 \times 10^{4}$ & - & - & - & $3.625 \times 10^{3}$ \\
\hline W45 & Cough, UTI & $2.9 \times 10^{4}$ & - & - & - & - \\
\hline
\end{tabular}

\section{Discussion}

In this study, herbal preparations contained varying degrees of both bacteria and fungi as common contaminants.This has also been reported in similar studies by Archibong and colleagues [20-22]. Of 
concern is the high levels of contaminants such as $B$. subtillis, $C$. freundi, $C$. divergens, E. cloacae and $P$. mirabilis although some had acceptable values for Enterobacter cloacae, Rhodotorula and Aspergillus spp, Staphylococcus Aureus, Klebsiella spp according to WHO standards. This is similar to studies done in Mwanza with the exception of Shigella and Salmonella that we didn't obtain [23, 24].

Contamination of these herbal preparations could be resulting from the methods involved in the production processes as previously reported by $[20,25,26]$. Storage conditions, methods of drying herbal raw materials such as roots, leaves and stems, bark, improper handling, and the soil from which raw materials are obtained may contribute to the presence of these contaminants in the herbal products.

Presence of microorganisms in therapeutic herbal preparations incapacitates the pharmacological activity of the herbal products and contributes to secondary infections to the consumers. Previous studies have reported that the majority of these isolates are implicated in causing various disease conditions including gastritis. The cultivation of high numbers of Bacillus subtilis could be because of inadequate heat processing methods, improper handling of the products, and contaminated processing equipment. Our results are in agreement with that obtained by Oluwatoyin and colleagues $[24,27]$ which found that most herbal remedies were contaminated because of improper handling of the products, and contaminated processing equipment used in the production process.

Bacillus subtilis is not considered a human pathogen nor is it toxigenic like some other members of the genus, however in immune-suppressed individuals, it's implicated in various systemic infections such as endocarditis, meningitis [26-28].

On the other hand, the presence of members of the Enterobacteriaceae family such as $C$. freundi, $C$. divergens, E. cloacae, P. mirabilis, Enterobacter cloacae and Klebsiella spp is an indication of fecal contamination. This revealed poor hygienic practices of the herbalists in the process of production and handling of these products $[24,25,29]$. These results are similar to those done in Croatia and Tanzania, .They are known food borne pathogens and thus implicated in food poisoning and diarrhea diseases [25, $30,31]$.

Not only did we obtain the above but also Staphylococcus aureus was also identified in this study, $S$. aureus has also been reported in similar study done in Brazil and Kenya [24, 25] except that its prevalence was higher compared to our study and its implicated in scalded skin syndrome, wound abscess, and gastroenteritis[25, 32].

Microbial analysis of these samples also indicated the presence of molds, especially Aspergillus and Rhodotorula species. These have also been reported in similar studies done in Brazil [25, 33]. Since fungi are ubiquitous in nature, their presence reveals that it could be because of improper storage and handling practices of raw materials during pre-and post-harvesting and processing periods. Rhodotorula spp is known to have high affinity for plastics, therefore its presence indicates poor packaging of the products since the majority of the herbal preparations were sold in unauthentic plastic bottles which appeared to have been used for other products such as commercial mineral water [34, 35].

Page $15 / 22$ 
With all negative impacts of the contaminants mentioned above, Rhodotorula was't left out. Previously it was considered nonpathogenic but has emerged as pathogenic opportunists that may colonize susceptible patients, and it causes bloodstream infections, meningeal and skin infections [36-38]. Aspergillus spp causes a range of diseases referred to as áspergillosis with a variety of clinical syndromes, the spectrum of these illness depending on host pathogen interactions. These include invasive pulmonary aspergillosis, chronic pulmonary aspergillosis, and allergic Broncho pulmonary aspergillosis.[39-41].

Invitro- antibacterial activity in this study was carried out on targeted standard organisms, namely, S.aureus ATTC 25923, E. coli ATTC 25922, P.aeruginosa ATTC 27583 and C. albicans ATTC 10231.

Herbal extracts have proven antibacterial activity in studies reported previously [26, 42-44]. This is similar to what we obtained in this study. We established that majority of the extracts were active against $S$ .aureus, followed by E.coli, C.albicans, and least against P.aeruginosa. This is in agreement with other studies by Shu and collegues $[26,43]$.

However, effectiveness was established by determining Minimum Inhibitory Concentrations, in this context, the most effective crude extract regarded as sensitive should have an MIC of $<100 \mathrm{mcg} / \mathrm{mL}$, and that $>1000 \mathrm{mcg} / \mathrm{mL}$ is regarded as resistant $[45,46]$.In our study, none of the samples had an MIC $<100 \mathrm{mcg} / \mathrm{mL}$, all were $>1000 \mathrm{mcg} / \mathrm{mL}$. This could be because of the inadequate and improper purification methods involved in extraction.

Our results are similar to those obtained in Northern Peru[47,48] but contrally from those obtained by Wong and colleagues[49, 50].

\section{Conclusion}

Herbal formulations in Mbarara are contaminated with various microbes and have very limited antimicrobial activity, herbalists therefore should be trained on good harvesting, safe handling, storage, and good manufacturing practices of these medicinal raw materials and their products, responsible authorities should enact policies and regulations to guide the herbalists and protect the public from adverse effects of consuming these unverified herbal medicinal remedies.

\section{Materials And Methods}

\section{Study site.}

Study was undertaken in Mbarara city in major divisions of Nyakayojo, Nyamitanga, Kakoba, Kakiika, Kamukuzi, and Biharwe.

\section{Study design.}

Cross-sectional laboratory-based study. 


\section{Sampling.}

Herbal products were randomly sampled at market price and the choice of herbal formulations was obtained by asking the vendors the herb treating a particular infection in local language and in this case skin infections such as boils, diarrhoea, stomach pain, respiratory tract, genital, urogenital and gastrointestinal tract infections were considered. Five out of the six divisions of Mbarara Municipality were randomly selected for sampling of herbal products.

\section{Sample size determination.}

A pilot study was done in two divisions of Mbarara Municipality to identify the common herbal remedies on the market and it was found out that Kakoba division had 11 different types of herbs treating different infections and Nyamitanga division had 7 different herbal remedies for different ailments giving a total of 18 herbal remedies for each division in the municipality with average of 9 therefore a total of 45 samples was used for the study.

\section{Inclusion criteria.}

Liquid formulations branded to treat cultivatable etiological agents and not expired at the time of conducting the study.

\section{Exclusion criteria.}

Herbal remedies used to treat non-communicable diseases.

\section{Data collection instruments/methods:}

Data collection commenced following a thorough explanation of the study objectives.

\section{Microbial analysis.}

\section{Preparation of culture media.}

All dehydrated media were prepared according to the manufacturer's instructions. They were mixed with distilled water and dissolved by gentle heat to boil. The media were sterilized in an autoclave at $121^{\circ} \mathrm{C}$ for $15 \mathrm{~min}$ at 15 pounds of pressure. The sterile media were then dispensed into sterilized petri dishes and allowed to cool. The sterility of the prepared media was checked by incubation of blindly selected plates at $37^{\circ} \mathrm{C}$ for $24 \mathrm{hrs}$.

\section{Determination of the presence of bacterial contaminants.}

Microbial parameters of significance such as colony forming units were determined by dispensing $1 \mathrm{~mL}$ of the herbal formulation into the middle of a sterile culture plate using a microliter pipette followed by addition of $15-20 \mathrm{~mL}$ of plate count agar. The mixture was gently shaken back and forth then round to allow uniform mixing of the agar and herbal extracts. It was left to stand for 30 minutes to solidify, and 
each of the samples were incubated at 37o, C for $48 \mathrm{hrs}$. CFUs were then determined by manual counting of distinct colonies and expressed in colony forming units per $/ \mathrm{mL}$.

\section{Identification of bacterial and fungal contaminants.}

Colonies that grew on plate count agar media were sub-cultured on blood agar, MacConkey or Sabouraud Dextrose Agar and incubated for $24 \mathrm{hrs}$ at $37^{\circ} \mathrm{C}$ for bacterial growth while $25-30^{\circ} \mathrm{C}$ for 3 days for fungal growth. Pure cultures were identified based on morphological features, cultural characteristics, staining properties, and biochemical reactions. Lactophenol blue stain was used to identify moulds with aid of microscope [19].

\section{Determination of antimicrobial activity of selected herbal product samples using agar diffusion assay.}

The herbal samples were further examined for antimicrobial activity against selected bacterial and fungal isolates, respectively.

All samples were tested against reference bacterial strains, namely, E. coli ATCC 25922, S. aureus ATCC 25923, P. aeruginosa ATCC 27583, and Candida albicans ATCC 10231.

Individual colonies of standard organisms were inoculated on Mueller Hinton agar for bacteria using sterile swabs, two holes of $8 \mathrm{~mm}$ diameter and equidistant from each other were bored into the plates using a sterile glass cork borer. A volume of $1 \mathrm{~mL}$ of herbal formulation and $1 \mathrm{~mL}$ of control drug ciprofloxacin for bacterial activity was dispensed into the holes and left to stand for 5 minutes to allow adequate diffusion of the samples. The plates were then taken for incubation at $37^{\circ} \mathrm{C}$ for $24 \mathrm{hrs}$.

The diameter of the zones of inhibition around each hole in the plate were measured in millimetres. The same procedure was repeated for the test with C. albicans ATCC 10231 but using Sabouraud Dextrose Agar and Fluconazole as control drugs and incubation at $25-30^{\circ} \mathrm{C}$ for $48 \mathrm{hrs}$.

\section{Determination of minimum inhibitory concentrations (MICs) of the herbal formulations using broth dilution assay.}

To determine the herbal MICs, $1 \mathrm{~mL}$ of the original herbal formulation was serially diluted in the ratio of $1 / 2,1 / 4,1 / 8,1 / 16,1 / 32$ using sterile water in bijou bottles, these were then seeded on to MHA for bacteria and SDA for fungal standards. The dilutions which inhibited growth of the test organisms were read as the MICs for each of the herbal formulations.

\section{Declarations}

\section{Ethical consideration.}

Ethical approval was sought from Research Ethics Committee (REC) of Mbarara University of Science and Technology (reference number MUREC 1/7). 
We blinded the products during practical procedures, analysis of samples, and dissemination of results of the study to ensure anonymity of the manufacturer and source of the product using letter codes followed by figures representing the sample number according to the sample size and this was W01-W45.

\section{Availability of data and materials}

Data and materials are readily available from the corresponding author upon request.

\section{Authors' contributions.}

GW, BM contributed in study conception and design, $\mathrm{CO}$ and KM Collected data, MC, HZ, IM, and GM participated in the laboratory analysis, $\mathrm{KK}$ and $\mathrm{CO}$ carried out data cleaning and analysis. MB and FT wrote the first draft of the manuscript while $\mathrm{HI}$ reviewed the manuscript and supervised the whole research process.

\section{Conflict of Interest}

The authors declare that they have no Conflict of interest.

\section{Acknowledgments}

We are grateful to our research assistants and staff of Mbarara University Microbiology department for all support given to us during data collection.

\section{Funding}

We did not receive funding for this study.

\section{References}

1. Pragati and Anjiika, The scope and market of alternative medicine and India's potential to become a global distributor International journal of Advance Research,Ideas And Innovations in Technology. 2019. 5 (2).

2. Abbasi, Umair , and Altaf, An ethnobotanical survey of indigenous medicinal plants in Hafizabad district, PunjabPakistan PLOS ONE 2017., 2017(2).

3. Sousa et al., Microbial contamination in herbal medicines: a serious health hazard to elderly consumers. BMC Complementary Medicine and Therapies, 2020. 20(17).

4. Ampofo, et al., Microbiological Profile of Some Ghanian Herbal Preparations-Safety Issues and Implications for the Health Professions. . Open Journal Of Medical Microbiology., 2012. 2: p. 121-130.

5. Jamison, Breman, and Measham, "Complementary and alternativemedicine," in Disease Control Priorities in Developing Countries, World Bank, Washington, DC, USA, 2006.

6. Sujatha Complementary and alternative therapies in palliative care: $A$ transition from modern medicine to traditional medicine in India. Journal of can cer Pain Symptom Palliation, 2005. 1: p. 25- 
9.

7. Jamison, et al., ., "Complementary and alternativemedicine," in Disease Control Priorities in Developing Countries, World Bank, Washington, DC, USA, 2nd edition, 2006. 2006.

8. Lopez , Hudson , and Towers Journal of Ethnopharmacology, 2001. 77: p. 189-96.

9. Mulligen , Kauffman , and Yu American Journal of medicine, 1993. 1993. 94: p. 313-28.

10. Singh et al., Journal of Antimicrobial Chemotherapy, 1992. 29: p. 159-68.

11. Ngezahayo et al., Medicinal plants used by Burundian traditional healers for the treatment of microbial diseases. Journal of Ethnopharmacology. 2015: p. 51.

12. Dieudonné, et al., Antimicrobial Activities of a Plethora of Medicinal Plant Extracts and Hydrolates against Human Pathogens and Their Potential to Reverse Antibiotic Resistance. International Journal of Microbiology 2015: p. 1-15.

13. Zhang et al., Antibacterial activity and mechanism of cinnamon essential oil against Escherichia coli and Staphylococcus aureus. . Food Control., 2015.

14. Zhang , K, and M, Quality of herbal medicines: challenges and solutions. . Complement Therapies in Medicine, 2019. 20(1): p. 100-106.

15. Gazzette, U., Indigenous and Complementary Medicine . 2015.

16. WHO, World Health Organisation strategy on traditional Medicine. 2013: p. 2014-2023.

17. Ingela et al. spontaneously reported adverse reactions in association with complementary and alternative medicine substances in Sweden,. Pharmacoepidemiology and drug safety. 18: p. 10391047.

18. Archibong, et al., Microbiological Assessment of Some Liquid Herbal Medications Sold in Awka Metropolis, Anambra State. Bioengineering and Bioscience . 2017. 5(3): p. 37-6.

19. Korir microbial and heavy metal contamination of selected medicinal herbal products sold in Nairobi, Kenya. 2017.

20. Archibong, et al., Microbiological Assessment of Some Liquid Herbal Medications Sold in Awka Metropolis, Anambra State. Bioengineering and Bioscience . 2017. 5(3): p. 37-46.

21. Czech, et al., Microbiological Status of Commercially Available Medicinal Herbal Drugs. PlantaMedica., 2001. 67: p. 263-269.

22. Shu, E.N., et al., Unwholesome Herbal Medicines Marketed in Enugu Metropolis, Enugu State, South Eastern Nigeria: Public Health Implications. Journal of Environmental Science and Public Health, 2019. 3(2): p. 122-132.

23. Clementine et al., Microbial contamination of traditional liquid herbal medicinal products marketed in Mwanza city: magnitude and risk factors. Pan African Medical Journal., 2016. 23(65).

24. Meshack, et al., Microbial Quality of Unregulated Herbal Medicinal Products in Kenya. African Journal of Pharmacology and Therapeutics., 2013. 2(3): p. 70-75.

25. Carolina, et al., Microbial contamination in herbal medicines: a serious health hazard to elderly consumers. BMC Complementary Medicine and Therapies., 2020. 20(17). 
26. Chakraborty et al., Microbiological quality and antimicrobial potential of extracts of different spices. Food Research., 2020. 4(2): p. 375-379.

27. Oluwatoyin and Adebayo Assessment of the microbial quality of some oral liquid herbal medicines marketed in Ile-Ife, South-western Nigeria. African Journal of Microbiology Research., 2016. 10(38): p. 1618-1624, .

28. KOSALEC, Josipa, and Siniša, CONTAMINANTS OF MEDICINAL HERBS AND HERBAL PRODUCTS. 2009. 60: p. 485-501.

29. Noor et al., Microbial contamination in herbal medicines available in Bangladesh. Bangladesh Med Res Counc Bull., 2013. 39: p. 124-129.

30. Mohammad, A.-M., et al., Food poisoning and intoxication: A global leading concern for human health in food safety and preservation. 2018, Elsevier. p. 307-352.

31. Gong, Z., et al., Characterization of a novel diarrheagenic strain of Proteus mirabilis associated with food poisoning in China. Frontiers in microbiology, 2019. 10: p. 2810.

32. Esimone et al. Susceptibilityresistance profile of microorganisms isolated from her bal medicine products sold in Nigeria. . Afr J Biotechnol. . 2007. 6(24): p. 2766-75.

33. Bugno, A. et al., Occurrence of toxigenic fungi in herbal drugs. Brazilian Journal of Microbiology, 2006. 37: p. 47-51.

34. Famewo, E.B., A.M. Clarke, and A.J. Afolayan, Fungal metagenomes in polyherbal medicines used for the treatment of tuberculosis. Journal of Pharmacognosy and Phytotherapy, 2018. 10(6): p. 102-109.

35. Mrozek-Szetela, A., P. Rejda, and K. Wińska, A Review of Hygienization Methods of Herbal Raw Materials. Applied Sciences, 2020. 10(22): p. 8268.

36. Aimee et al., Risk of Fungemia due to Rhodontorula and Antifungal Susceptibility Testing due to Rhodontorula. Journal of clinical microbiology, 2003: p. 5233-5235.

37. Potenza, L. et al., Rhodotorula infection in haematological patients: Risk factors and outcomes. Mycoses, 2019. 62(3): p. 223-229.

38. Deligios, M. et al., Draft genome sequence of Rhodotorula mucilaginosa, an emergent opportunistic pathogen. Genome announcements, 2015. 3(2).

39. Blaize, M., et al., Fatal invasive aspergillosis and coronavirus disease in an immunocompetent patient. Emerging infectious diseases, 2020. 26(7): p. 1636.

40. Schauwvlieghe, A.F., et al., Invasive aspergillosis in patients admitted to the intensive care unit with severe influenza: a retrospective cohort study. The Lancet Respiratory Medicine, 2018. 6(10): p. 782792.

41. Latgé, J.-P. and G. Chamilos, Aspergillus fumigatus, and Aspergillosis in 2019. Clinical microbiology reviews, 2019. 33(1).

42. De Souza et al., Antimicrobial effectiveness of spices: An approach for use in food conservation systems. . Brazilian Archives of Biology and Technology, , 2005. 48(4): p. 549-558. 
43. Nam-Hui Yim et al., Screeningofaqueousextractsofmedicinalherbsfor antimicrobialactivityagainstoralbacteria Integrative Medicine Research, 2013. 2: p. 18-24.

44. Pavithra et al., Antibacterial activity of plants used in Indian herbal medicine. International Journal of Green Pharmacy., 2010.

45. MULAUDZI et al., Antimicrobial activity, cytotoxicity evaluation, and heavymetal content of five commonly used South African herbal mixtures. . South African Journal of Botany., 2017.

46. RíOS and RECIO, Medicinal plants and antimicrobial activity. Journal of Ethnopharmacology . 2005. 100: p. 80-84.

47. Bussmann et al., Minimum inhibitory concentrations of medicinal plants used in Northern Peru as antibacterial remedies. Journal of Ethnopharmacology . 2010. 132.(1): p. 101-108.

48. Pesewu, Cutler, and Humber Antibacterial activity of plants used in traditional medicine of Ghana with particular reference to MRSA. Journal of Ethnopharmacology . 2008. 116: p. 102-111.

49. Wong, R. et al., Antimicrobial activity of Chinese medicine herbs against common bacteria in oral biofilm. A pilot study. International journal of oral and maxillofacial surgery, 2010. 39(6): p. 599-605.

50. Sen, A. and A. Batra Evaluation of antimicrobial activity of different solvent extracts of medicinal plants: Melia azedarach L. Int J Curr Pharm Res, 2012. 4(2): p. 67-73. 